\title{
Penman and Thornthwaite Equations for Estimating Reference Evapotranspiration Under Semi-Arid Environment
}

\author{
Muhammad Hafeez ${ }^{1, *}$, Allah Bakhsh Gulshan², Abdul Basit ${ }^{2}$, Zia Ahmad Chattha ${ }^{3}$, \\ Alamgir Akhtar Khan ${ }^{4}$, Muhammad Adnan Majeed ${ }^{5}$, Fatima Tahira ${ }^{6}$ \\ ${ }^{1}$ Department of Agricultural Engineering, Faculty of Agricultural sciences and Technology, Bahauddin Zakariya University, Multan, Pakistan \\ ${ }^{2}$ Department of Botany, Ghazi University, Dera Ghazi Khan, Pakistan \\ ${ }^{3}$ Faculty of Agricultural Engineering, University of Agriculture, Faisalabad, Pakistan \\ ${ }^{4}$ Department of Agricultural Engineering, Muhammad Nawaz Sharif University of Agriculture, Multan, Pakistan \\ ${ }^{5}$ School of Engineering, University of Waikato, Hamilton, New Zealand \\ ${ }^{6}$ Department of Mathematics, Institute of Southern Punjab, Multan, Pakistan
}

Email address:

mh9589041@gmail.com (M. Hafeez)

${ }^{*}$ Corresponding author

\section{To cite this article:}

Muhammad Hafeez, Allah Bakhsh Gulshan, Abdul Basit, Zia Ahmad Chattha, Alamgir Akhtar Khan, Muhammad Adnan Majeed, Fatima Tahira. Penman and Thornthwaite Equations for Estimating Reference Evapotranspiration Under Semi-Arid Environment. Journal of Plant Sciences. Vol. 8, No. 5, 2020, pp. 146-151. doi: 10.11648/j.jps.20200805.16

Received: April 10, 2020; Accepted: August 22, 2020; Published: September 24, 2020

\begin{abstract}
The estimation of reference evapotranspiration (ETo) is required for effective development and management of agriculture water systems. In order to define the most accurate method to estimate ETo in semi-arid climatic environment of Faisalabad, Lahore and Peshawar. Penman ETo method and Thornthwaite ETo method are compared with standard PenmanMonteith (PM) ETo method. The statistical results show that the Penman ETo method overestimate ETo as compared to the PM ETo method in all the semi-arid climatic regions of Faisalabad, Lahore and Peshawar by $34.91 \%, 39.51 \%$ and $30.75 \%$, respectively. The coefficient of determination $\left(\mathrm{R}^{2}\right)$ were $0.98,0.98$ and 0.99 at Faisalabad, Lahore and Peshawar weather stations, respectively. The root mean square error (RMSE) are $2.47 \mathrm{~mm} /$ day, $2.64 \mathrm{~mm} /$ day and $2.19 \mathrm{~mm} /$ day at Faisalabad, Lahore and Peshawar weather station, respectively. The mean bias error (MBE) of- $2.41 \mathrm{~mm} / \mathrm{day},-2.58 \mathrm{~mm} / \mathrm{day}$ and-2.13 $\mathrm{mm} /$ day are noted at Faisalabad, Lahore and Peshawar weather stations, respectively. The statistical results of Thornthwaite (Th) ETo method with PM ETo method indicate underestimation of ETo in winter season and overestimation of ETo in summer season by $13.81 \%, 22.43 \%$ and $14.54 \%$ at Faisalabad, Lahore and Peshawar stations, respectively. The coefficient of determination $\left(\mathrm{R}^{2}\right)$ of Thornthwait ETo method when compared with PM ETo method 0.92, 0.89 and 0.95 are noted at Faisalabad, Lahore and Peshawar weather stations, respectively. The root mean square error (RMSE) are $2.14 \mathrm{~mm} / \mathrm{day}, 2.36$ $\mathrm{mm} /$ day and $1.16 \mathrm{~mm} /$ day at Faisalabad, Lahore and Peshawar weather stations, respectively. The mean bias error (MBE) are$0.68 \mathrm{~mm} /$ day, $-1.12 \mathrm{~mm} /$ day and $0.61 \mathrm{~mm} /$ day at Faisalabad, Lahore and Peshawar weather stations, respectively. Overall, Thornthwaite method gave better estimation of ETo than Penman ETo method at all the Weather stations.
\end{abstract}

Keywords: Penman, Thornthwaite, Penman-Monteith, Reference Evapotranspiration, Semi-arid

\section{Introduction}

Pakistan lies in arid to semi-arid region where average annual rainfall is 254 to $356 \mathrm{~mm}$ against a potential demand (of water for maximum crop production) of $1778 \mathrm{~mm}$. This gap between the demands and supplies is met through applying irrigation. Moreover, the country is facing threat of rapidly increasing population with the annual growth rate of 2.05 percent. It has been observed that water availability for agriculture is expected to decline globally to 62 percent by 
2020 as was available (72\%) in 1995 and from $87 \%$ to $73 \%$ in developing countries [1]. Reference evapotranspiration (ETo) is one of the most significant factor to design and manage water reservoirs [2]' scheme of irrigation structures [3], effective irrigation management [4] and hydrological and meteorological investigations [5]. Types of crop and land use affect the evapotranspiration process [6]. The most accurate ETo method for the estimation of ETo is lysimeter [7-8]. Since lysimeters manufacturing is very expenses, experimental ETo methods are generally applied to estimate ETo. Numerous researchers have argued that PenmenMonteith (PM) ETo method can be applied as a reference ETo method as compared to the other experimental ETo methods [9-12]. The Penman-Monteith (PM) ETo method requires large number of weather parameters i-e air temperature, humidity, solar radiation, wind speed etc. But, availability of these weather parameters is not accessible at all the weather stations of the world especially in developing country like Pakistan. Therefore, it appears reasonably to substitute it by other ETo methods which require small number of weather parameters [13]. The accuracy of a particular ETo method depends greatly on the climatic situations of the research area [14]. For humid subtropical weather climatic conditions Penman-Monteith (PM) ETo method is commonly suggested [15-16].

Many researchers including [17-20] revealed that temperature and radiation dependent ETo methods lean towards the highest and pan-coefficient dependent ETo methods give lowest ETo values. It is concluded that in dry and semi-dry climatic conditions solar radiation-dependent ETo methods give poor results [21]. However, application of regionally modified radiation-dependent ETo methods can give more accurate results than air temperature dependent ETo methods and even complex ETo methods [22-23]. As the accuracy of estimated values of ETo by different ETo methods is significant for water resources design and management, proper irrigation timing, control and agricultural efficiency; it has given rise to many researchers that were carried out in various regions of the globe to determine the most accurate ETo method which is appropriate for estimation of ETo in such regions [24]. A study is carried out to compare the various ETo methods including Turc [25], Blaney-Criddle [26], Hamon [27], Thornthwaite [28] and Priestley-Taylor [29] ETo methods against standard Penman-Monteith [30] ETo method for the estimation of ETo by applying weather parameters of 12 various weather stations. The results of the study indicated that the Turc and Penman-Monteith (PM) method showed the most accurate results [31]. Another research is conducted to evaluate the accuracy of 9 ETo methods against PenmanMonteith (PM) ETo method to estimate ETo. The conclusion of research showed that the Blaney-Criddle (BC) ETo indicated the most accurate ETo estimation and the Thornthwaite ETo method indicated the poor results of ETo estimation [32]. The main objective of this research is to compare the performance of Penman and Thornthwaite ETo methods against standard PM ETo method under semi-arid climatic conditions of Lahore, Faisalabad and Peshawar, Pakistan.

\section{Materials and Methods}

\subsection{Geographical Area and Weather Data Set}

The mean monthly weather data of three weather stations of semi-arid regions (Lahore, Faisalabad and Peshawar) is used to estimate reference evapotranspiration (ETo) by Penman and Thornthwaite ETo methods. The mean monthly weather data period, climate conditions and Global Positioning System (GPS) of weather stations used in the study are given in the table.

Table 1. Global Positioning System and climate of weather stations of study regions.

\begin{tabular}{|c|c|c|c|c|c|}
\hline Station & Latitude & Longitude & Elevation (m) & Data Period & Climate \\
\hline Lahore & $31.33^{\circ} \mathrm{N}$ & $74.20^{\circ} \mathrm{E}$ & 214.0 & $2000-2009$ & hot semi-arid \\
\hline Faisalabad & $31.26^{\circ} \mathrm{N}$ & $73.08^{\circ} \mathrm{E}$ & 185.6 & $2001-2010$ & hot semi-arid \\
\hline Peshawar & $34.02^{\circ} \mathrm{N}$ & $71.56^{\circ} \mathrm{E}$ & 327.0 & $2000-2007$ & hot semi-arid \\
\hline
\end{tabular}

Methods for estimation of ETo

\subsection{Penman-Monteith (PM) ETo Method}

In this research paper, the Penman-Monteith (PM) ETo method [30] is recommended as the reference ETo method for estimation ETo. The accuracy of this ETo method has been proved by many researchers under various weather conditions [33-36]. The Penman-Monteith (PM) ETo method presented by [30] is given as:

$$
\text { ETo }=\frac{0.408\left(\mathrm{R}_{\mathrm{n}}-\mathrm{G}\right)+900 \gamma\left(\frac{\mathrm{U}_{2}}{\mathrm{~T}+273}\right) \mathrm{e}_{\mathrm{s}}-\mathrm{e}_{\mathrm{a}}}{\Delta+\gamma\left(1+0.34 \mathrm{U}_{2}\right)}
$$

Where, ETo is reference crop evapotranspiration $(\mathrm{mm} /$ day $) ; \Delta$ is slope of the saturation vapor pressure function $\left(\mathrm{kPa}\left({ }^{\circ} \mathrm{C}\right)^{-1}\right) ; \mathrm{Rn}$ is net solar radiations $\left(\mathrm{MJ} \mathrm{m}^{-2}\right.$ day $^{-}$ $\left.{ }^{1}\right) ; \mathrm{G}$ is earth heat flux thickness $\left(\mathrm{MJ} \mathrm{m}^{-2}\right.$ day $\left.^{-1}\right) ; \mathrm{T}$ is average atmospheric temperature $\left({ }^{\circ} \mathrm{C}\right) ; \mathrm{U}_{2}$ is the mean 24 hour air velocity at $2 \mathrm{~m}$ elevation $\left(\mathrm{ms}^{-1}\right) ;\left(\mathrm{e}_{\mathrm{s}-} \mathrm{e}_{\mathrm{a}}\right)$ is the vapor pressure deficit $(\mathrm{kPa})$; and $\gamma$ is psychometric constant $(\mathrm{kPa}$ $\left.\left({ }^{\circ} \mathrm{C}\right)^{-1}\right)$ The estimation of all weather data essential for estimation of ETo followed the method of [30].

\subsection{Thornthwaite Method}

The Thornthwaite ETo method had been developed in 1948 by [28]. This ETo method is given as:

$$
\mathrm{ETo}=\mathrm{ET}_{\mathrm{gr}}\left(\frac{\mathrm{N}}{12}\right)\left(\frac{\mathrm{d}_{\mathrm{m}}}{30}\right)
$$




$$
\begin{aligned}
& \left.\mathrm{ET}_{\mathrm{gr}}=16 \frac{10 \mathrm{~T}_{\mathrm{m}}}{\mathrm{I}}\right)^{\alpha} \\
& \mathrm{I}=\sum_{\mathrm{i}=1}^{12}\left(\frac{\mathrm{T}_{\mathrm{m}}}{5}\right)^{1.154}
\end{aligned}
$$

Where, $\mathrm{N}$ is the maximum number of sunny hours in function of the month latitude; $d_{m}$ is the number of day per month; $\mathrm{ET}_{\mathrm{gr}}$ is the gross evapotranspiration; $\mathrm{T}_{\mathrm{m}}$ is the mean temperature $\left({ }^{\circ} \mathrm{C}\right)$; I is the monthly heat index.

$$
\alpha=0.49239+1792 \times 10^{-5} \mathrm{I}-771 \times 10^{-7} \mathrm{I}^{2}+675 \times 10^{-9} \mathrm{I}^{3}
$$

\subsection{Penman Method}

The Penman [37] ETo method is given as:

$$
\text { ETo }=\frac{\frac{\Delta}{\Delta+\gamma}\left(\mathrm{R}_{\mathrm{n}}-\mathrm{G}\right)+\frac{\gamma}{\Delta+\gamma} 6.43\left(\left(1+0.53 \mathrm{u}_{2}\left(\mathrm{e}_{\mathrm{s}}-\mathrm{e}_{\mathrm{a}}\right)\right)\right.}{\lambda}
$$

Where, ETo is the reference evapotranspiration ( $\mathrm{mm} /$ day); $\Delta$ is slope of the saturation vapor pressure function $\left(\mathrm{kPa}\left({ }^{\circ} \mathrm{C}\right)^{-}\right.$ $\left.{ }^{1}\right)$; $\mathrm{Rn}$ is net solar radiations $\left(\mathrm{MJ} \mathrm{m}^{-2}\right.$ day $\left.^{-1}\right)$; $\mathrm{G}$ is earth heat flux thickness $\left(\mathrm{MJ} \mathrm{m}^{-2} \mathrm{day}^{-1}\right) ; \mathrm{u}_{2}$ is the mean 24-hour air velocity at $2 \mathrm{~m}$ elevation $\left(\mathrm{ms}^{-1}\right) ;\left(\mathrm{e}_{\mathrm{s}-} \mathrm{e}_{\mathrm{a}}\right)$ is the vapor pressure deficit $(\mathrm{kPa}) ; \gamma$ is psychometric constant $\left(\mathrm{kPa}\left({ }^{\circ} \mathrm{C}\right)^{-1}\right)$ and $\lambda$ is the latent heat of vaporization in $\mathrm{MJ} \mathrm{kg}^{-1}\left(\lambda=2.45 \mathrm{MJ} \mathrm{kg}^{-1}\right.$ at a temperature of $20^{\circ} \mathrm{C}$ ).

\subsection{Evaluation Criteria}

In this study, the root mean square error (RMSE), percentage error of estimate (PE), mean bias error (MBE) and coefficient of determination (R2) are used for the evaluation of the ETo methods. The RMSE, PE, MBE and $\mathrm{R}^{2}$ are defined as:

$$
\begin{aligned}
\text { RMSE } & =\sqrt{\frac{\sum_{\mathrm{i}=1}^{\mathrm{n}}\left(\mathrm{P}_{\mathrm{i}}-\mathrm{O}_{\mathrm{i}}\right)^{2}}{\mathrm{n}}} \\
\% \mathrm{PE} & =\left[\frac{\overline{\mathrm{P}}-\overline{\mathrm{O}}}{\overline{\mathrm{O}}}\right] \times 100 \\
\mathrm{MBE} & =\frac{\sum_{\mathrm{i}=1}^{\mathrm{n}}\left(\mathrm{P}_{\mathrm{i}}-\mathrm{O}_{\mathrm{i}}\right)}{\mathrm{n}}
\end{aligned}
$$

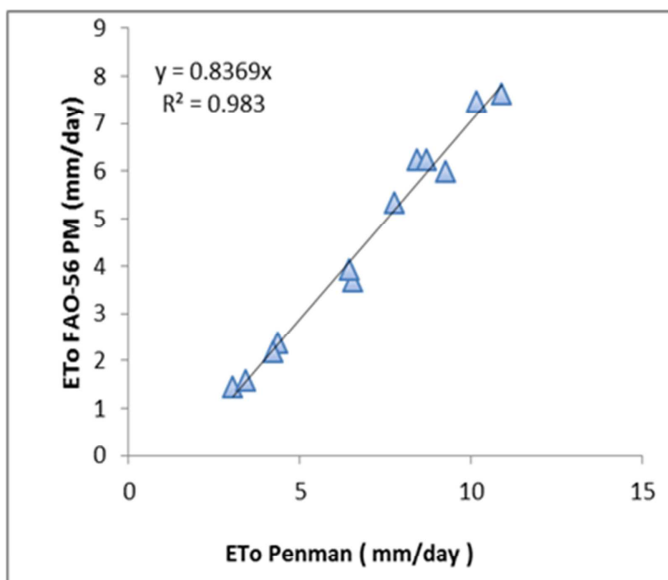

(a)

$$
\mathrm{R}^{2}=\frac{\left[\sum_{\mathrm{i}=1}^{\mathrm{n}}\left(\mathrm{P}_{\mathrm{i}}-\overline{\mathrm{P}}\right)\left(\mathrm{O}_{\mathrm{i}}-\overline{\mathrm{O}}\right)\right]^{2}}{\left.\sum_{\mathrm{i}=1}^{\mathrm{n}}\left(\mathrm{P}_{\mathrm{i}}-\overline{\mathrm{P}}\right)^{2} \sum_{\mathrm{i}}^{\mathrm{n}} \mathrm{O}_{\mathrm{i}}-\overline{\mathrm{O}}\right)^{2}}
$$

Where, Pi are the projected values and $\mathrm{Oi}$ are observed values. $\bar{P}$ is the mean of Pi and $\bar{O}$ is the mean of Oi, and $\mathrm{n}$ is the whole number of values.

\section{Results and Discussion}

The Penman ETo method and Thornthwaite ETo method that are temperature dependent ETo methods are compared with standard Penman-Monteith ETo method in different semi-arid climatic regions of Lahore, Faisalabad and Peshawar. According to the statistical analysis applied between Penman and PM ETo methods, the Penman ETo method indicated overestimation of ETo by $34.91 \%$ at Faisalabad weather station as concluded by [38] as shown in Figure 1 (a) and Table 2. The difference of variation between Penman and PM ETo methods has coefficient of determination $\left(\mathrm{R}^{2}\right)$ of 0.98 with root mean square error (RMSE) of $2.47 \mathrm{~mm} /$ day and mean bias error (MBE) of-2.41 $\mathrm{mm}$ /day at Faisalabad weather station. The statistical results between Thornthwaite ETo method and PM ETo method show that the Thornthwaite ETo method indicated underestimation in winter and overestimation in summer by $13.81 \%$ at Faisalabad station as concluded by [39-40], as shown in 1 (b) and table 2. The difference of variation between Thornthwaite ETo method and PM ETo method has coefficient of determination $\left(\mathrm{R}^{2}\right)$ of 0.92 with root mean square error (RMSE) of $2.14 \mathrm{~mm} /$ day and mean bias error (MBE) of- $0.68 \mathrm{~mm} /$ day.

Table 2. Statistical analysis of ETo calculated by Penman and Thornthwaite ETo methods compared with PM ETo method at Faisalabad station.

\begin{tabular}{lllll}
\hline Method & RMSE & $\mathbf{R}^{\mathbf{2}}$ & MBE & \% Error \\
\hline Penman & 2.47 & 0.98 & -2.41 & 34.91 \\
Thornthwaite & 2.14 & 0.92 & -0.68 & 13.81 \\
\hline
\end{tabular}

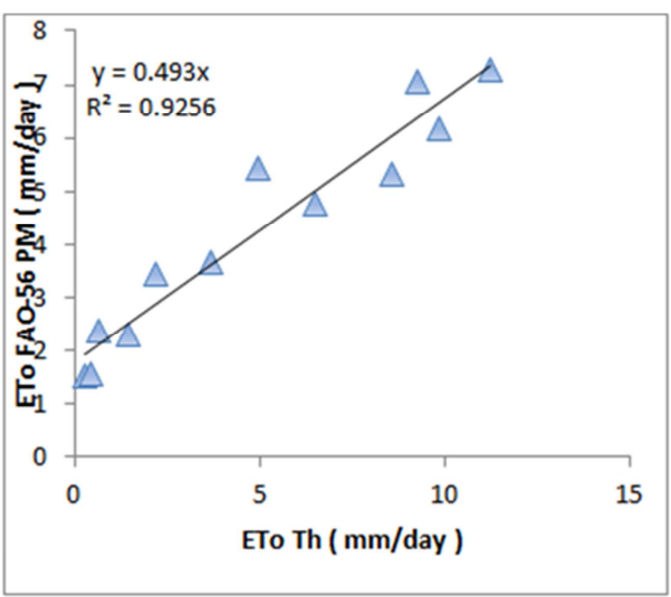

(b)

Figure 1. Comparison of ETo by (a) Penman and (b) Thornthwaite ETo methods with PM ETo method at Faisalabad station. 
The monthly comparison of ETo estimated by Penman and PM ETo method at Lahore weather station indicate that the ETo estimated by Penman ETo method overestimated the PM ETo method by $39.51 \%$ as concluded by [41] as shown in the figure 2 (a) and table 3 . The difference of variation between Penman ETo method and PM ETo method has coefficient of determination $\left(\mathrm{R}^{2}\right)$ of 0.98 with root mean square

RMSE of $2.64 \mathrm{~mm} /$ day and MBE of $-2.58 \mathrm{~mm} /$ day at Lahore weather station as shown in table 3. The Thornthwaite ETo method indicate underestimation of ETo in first 3 and last months (January, February, March and December) and overestimated ETo in the remaining months

of the year by $22.43 \%$ as concluded by [42] as shown in the Figure 2 (b) and in Table 3. The difference of variation between Penman ETo method and PM ETo method has $\mathrm{R}^{2}$ of 0.89 with RMSE of $2.36 \mathrm{~mm} /$ day and MBE of $-1.12 \mathrm{~mm} /$ day at Lahore weather station as shown in the Table 3.

Table 3. Statistical analysis of ETo calculated by Penman and Thornthwaite ETo methods compared with PM ETo method at Lahore station.

\begin{tabular}{lllll}
\hline Method & RMSE & $\mathbf{R}^{\mathbf{2}}$ & MBE & \% Error \\
\hline Penman & 2.64 & 0.98 & -2.58 & 39.51 \\
Thornthwaite & 2.36 & 0.89 & -1.12 & 22.43 \\
\hline
\end{tabular}

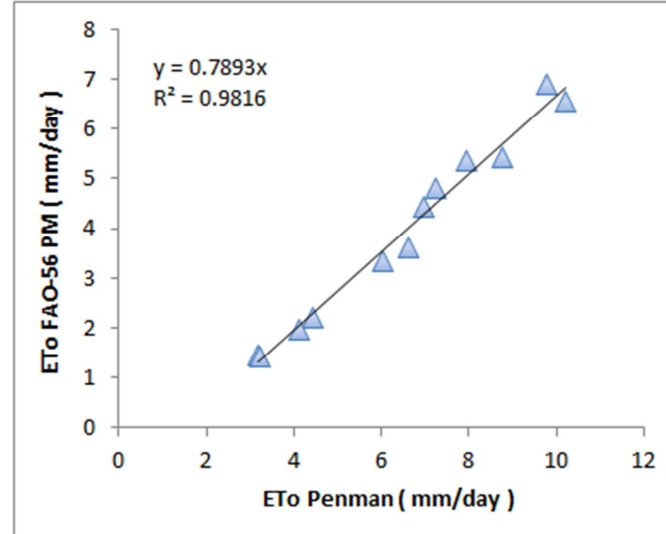

(a)

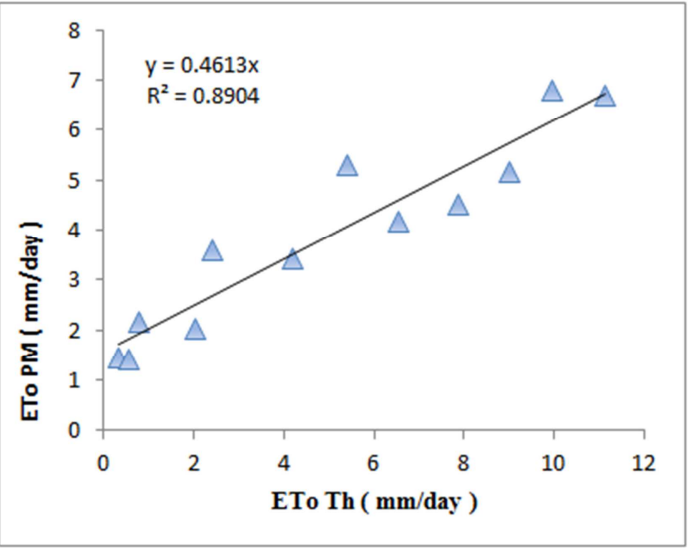

(b)

Figure 2. Comparison of ETo (a) Penman (b) Thornthwaite ETo methods with PM ETo method at Lahore station.

The statistical analysis between Penman ETo method and PM ETo method at Peshawar weather station indicate that Penman ETo method show overestimation of ETo by $30.75 \%$ as compared to the PM ETo method as concluded by [43] as shown in figure 3 (a) and in Table 4. The difference of variation among Penman ETo method and PM ETo method has $\mathrm{R}^{2}$ of 0.99 with RMSE of $2.19 \mathrm{~mm} /$ day and MBE of- 2.13 $\mathrm{mm} /$ day. The mean monthly comparison between Thornthwaite ETo method and PM ETo method at Peshawar weather station indicate that Thornthwaite ETo method overestimated in 3 months of summer (June, July and August) and underestimated in the remaining months of the year by $14.54 \%$ as concluded by [44] shown in the Figure 3 (b) and table 4. The variation difference between Thornthwaite ETo method and PM ETo method has $\mathrm{R}^{2}$ of 0.95 with RMSE of $1.16 \mathrm{~mm} /$ day and MBE of $0.61 \mathrm{~mm} /$ day.

Table 4. Statistical analysis of ETo calculated by Penman and Thornthwaite ETo methods compared with PM ETo method at Peshawar station.

\begin{tabular}{lllll}
\hline Method & RMSE & $\mathbf{R}^{2}$ & MBE & \% Error \\
\hline Penman & 2.19 & 0.99 & -2.13 & 30.75 \\
Thornthwaite & 1.16 & 0.95 & 0.61 & 14.54 \\
\hline
\end{tabular}

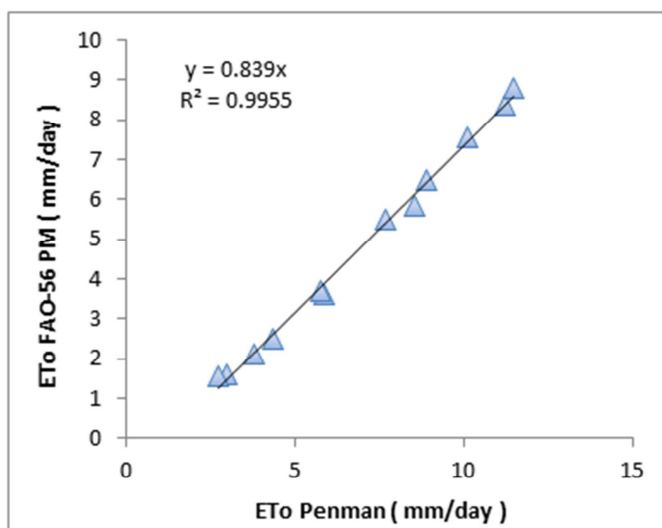

(a)

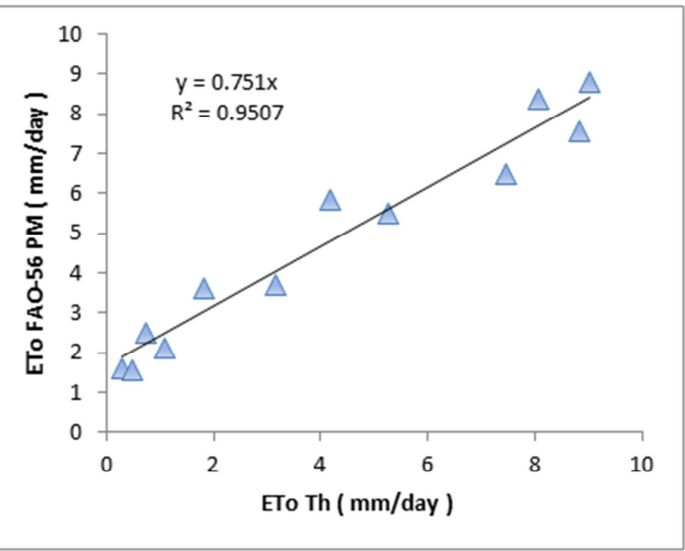

(b)

Figure 3. Comparison of ETo by (a) Penman (b) Thornthwaite ETo methods with PM ETo method at Peshawar station. 


\section{Conclusion}

This study compared the Penman and Thornthwaite ETo methods with PM ETo method to estimate ETo in different semi-arid climatic regions. The PM ETo method has been taken as reference ETo method as stated by many researchers including [45-46]. The statistical results show that the Penman ETo method overestimated PM ETo method for estimation of ETo at all the weather stations (Faisalabad, Lahore and Peshawar) of semi-arid climatic conditions. The Thornthwaite ETo method underestimated PM ETo method in winter season and overestimated PM ETo method in summer season in semi-arid climatic conditions of Faisalabad, Lahore and Peshawar weather stations. Overall, Thornthwaite ETo method gave better estimation of ETo than Penman ETo method at all the weather stations.

\section{Acknowledgements}

The authors would like to thank Pakistan Metrological Department, Lahore and Peshawar for providing the climatic data records used in this research.

\section{Disclosure Statement}

No potential conflict of interest was reported by the authors.

\section{References}

[1] Chatha, Z. A., Arshad, M., Bakhah, A. and Shakoor, A., 2015. STATISTICAL ANALYSIS FOR LINING THE WATERCOURSES. J. Agric. Res, 53 (1).

[2] Zarei, A. R., Zare, S. and Parsamehr, A. H., 2015. Comparison of several methods to estimate reference evapotranspiration. West African Journal of Applied Ecology, 23 (2), pp. 17-25.

[3] Fooladmand, H. R., 2012. Comparing reference evapotranspiration using actual and estimated sunshine hours in south of Iran. African Journal of Agricultural Research, 7 (7), pp. 1164-1169.

[4] Berti, A., Tardivo, G., Chiaudani, A., Rech, F. and Borin, M., 2014. Assessing reference evapotranspiration by the Hargreaves method in north-eastern Italy. Agricultural Water Management, 140, pp. 20-25.

[5] Kisi, O., 2014. Modeling solar radiation of Mediterranean region in Turkey by using fuzzy genetic approach. Energy, 64, pp. 429-436.

[6] Majeed, A., Mehmood, S., Sarwar, K., Nabi, G. and Kharal, M. A., 2017. Assessment of Reference Evapotranspiration by the Hargreaves Method in Southern Punjab Pakistan. European Journal of Advances in Engineering and Technology, 4 (1), pp. 64-70.

[7] Xu, C. Y. and Chen, D., 2005. Comparison of seven models for estimation of evapotranspiration and groundwater recharge using lysimeter measurement data in Germany. Hydrological Processes: An International Journal, 19 (18), pp. 3717-3734.
[8] Valipour, M., 2015. Study of different climatic conditions to assess the role of solar radiation in reference crop evapotranspiration equations. Archives of Agronomy and Soil Science, 61 (5), pp. 679-694.

[9] Azhar, A. H. and Perera, B. J. C., 2011. Evaluation of reference evapotranspiration estimation methods under southeast Australian conditions. Journal of Irrigation and Drainage Engineering, 137 (5), pp. 268-279.

[10] da Silva, V. J., Carvalho, H. D. P., da Silva, C. R., Camargo, R. D. and Teodoro, R. E. F., 2011. Performance of different methods of estimating the daily reference evapotranspiration in Uberlandia, MG. Bioscience Journal, 27 (1), pp. 95-101.

[11] Tabari, H., Grismer, M. E. and Trajkovic, S., 2013. Comparative analysis of 31 reference evapotranspiration methods under humid conditions. Irrigation Science, 31 (2), pp. 107-117.

[12] DeJonge, K. C., Ahmadi, M., Ascough II, J. C. and Kinzli, K. D., 2015. Sensitivity analysis of reference evapotranspiration to sensor accuracy. Computers and Electronics in Agriculture, 110, pp. 176-186.

[13] Hafeez, M. and Khan, A. A., 2018. Assessment of Hargreaves and Blaney-Criddle methods to estimate reference evapotranspiration under coastal conditions. American Journal of Science, Engineering and Technology, 3 (4), pp. 65-72.

[14] Mehdizadeh, S., Saadatnejadgharahassanlou, H. and Behmanesh, J., 2017. Calibration of Hargreaves-Samani and Priestley-Taylor equations in estimating reference evapotranspiration in the Northwest of Iran. Archives of Agronomy and Soil Science, 63 (7), pp. 942-955.

[15] Yoder, R. E., Odhiambo, L. O. and Wright, W. C., 2005. Evaluation of methods for estimating daily reference crop evapotranspiration at a site in the humid southeast United States. Applied engineering in agriculture, 21 (2), pp. 197202.

[16] McMahon, T. A., Peel, M. C., Lowe, L., Srikanthan, R. and McVicar, T. R., 2013. Estimating actual, potential, reference crop and pan evaporation using standard meteorological data: a pragmatic synthesis. Hydrol. Earth Syst. Sci, 17 (4), pp. 1331-1363.

[17] Yates, D. and Strzepek, K. M., 1994. Comparison of models for climate change assessment of river basin runoff.

[18] Alexandris, S., Stricevic, R. and Petkovic, S., 2008. Comparative analysis of reference evapotranspiration from the surface of rainfed grass in central Serbia, calculated by six empirical methods against the Penman-Monteith formula. European Water, 21 (22), pp. 17-28.

[19] Tukimat, N. N. A., Harun, S. and Shahid, S., 2012. Comparison of different methods in estimating potential evapotranspiration at Muda Irrigation Scheme of Malaysia. Journal of Agriculture and Rural Development in the Tropics and Subtropics (JARTS), 113 (1), pp. 77-85.

[20] Tahashildar, M., Bora, P. K., Ray, L. I. and Thakuria, D., 2017. Comparison of different reference evapotranspiration $\left(\mathrm{ET}^{\wedge}\right.$ sub $0^{\wedge}$ ) models and determination of crop-coefficients of french bean (Phesiolus vulgaris.) in mid hill region of Meghalaya. Journal of Agrometeorology, 19 (3), pp. 233-237. 
[21] Er-Raki, S., Chehbouni, A., Khabba, S., Simonneaux, V., Jarlan, L., Ouldbba, A., Rodriguez, J. C. and Allen, R., 2010. Assessment of reference evapotranspiration methods in semiarid regions: can weather forecast data be used as alternate of ground meteorological parameters? Journal of Arid Environments, 74 (12), pp. 1587-1596.

[22] Bois, B., Pieri, P., Leeuwen, C. V. and Gaudillere, J. P., 2005. Sensitivity analysis of the Penman-Monteith evapotranspiration formula and comparison of empirical methods used in viticulture soil water balance. In XIV International GESCO Viticulture Congress, Geisenheim, Germany, 23-27 August, 2005 (pp. 187-193). Groupe d'Etude des Systemes de COnduite de la vigne (GESCO).

[23] Schneider, K., Ketzer, B., Breuer, L., Vaché, K. B., Bernhofer, C. and Frede, H. G., 2007. Evaluation of evapotranspiration methods for model validation in a semi-arid watershed in northern China.

[24] Gocić, M., Motamedi, S., Shamshirband, S., Petković, D., Ch, S., Hashim, R. and Arif, M., 2015. Soft computing approaches for forecasting reference evapotranspiration. Computers and Electronics in Agriculture, 113, pp. 164-173.

[25] Turc, L., 1961. Estimation of irrigation water requirements, potential evapotranspiration: a simple climatic formula evolved up to date. Ann. Agron, 12 (1), pp. 13-49.

[26] Blaney, H. F. and Criddle, W. D., 1950. Determining water needs from climatological data. USDA Soil Conservation Service. SOS-TP, USA, pp. 8-9.

[27] Haith, D. A. and Shoemaker, L. L., 1987. Generalized Watershed Loading Functions for Stream Flow Nutrients 1. JAWRA Journal of the American Water Resources Association, 23 (3), pp. 471-478.

[28] Thornthwaite, C. W., 1948. An approach toward a rational classification of climate. Geographical review, 38 (1), pp. 5594.

[29] Priestley, C. H. B. and Taylor, R. J., 1972. On the assessment of surface heat flux and evaporation using large-scale parameters. Monthly weather review, 100 (2), pp. 81-92.

[30] Allen, R. G., Pereira, L. S., Raes, D. and Smith, M., 1998. Crop Evapotranspiration-Guidelines for computing crop water requirements-FAO Irrigation and drainage paper 56. Fao, Rome, 300 (9), p. D05109.

[31] Le, T. P. Q., Seidler, C., Kändler, M. and Tran, T. B. N., 2012. Proposed methods for potential evapotranspiration calculation of the Red River basin (North Vietnam). Hydrological Processes, 26 (18), pp. 2782-2790.

[32] Niaghi, A. R., Majnooni-Heris, A., Haghi, D. Z. and Mahtabi, G., 2013. Evaluate several potential evapotranspiration methods for regional use in Tabriz, Iran. Journal of Applied Environmental and Biological Sciences, 3 (6), pp. 31-41.

[33] Ravelli, F. and Rota, P., 1999. Monthly frequency maps of reference evapotranspiration and crop water deficits in southern italy. Rome: Irrigation Experimentation Office of the Former Southern Italy Development Agency.

[34] Irmak, S., Allen, R. G. and Whitty, E. B., 2003. Daily grass and alfalfa-reference evapotranspiration estimates and alfalfato-grass evapotranspiration ratios in Florida. Journal of Irrigation and Drainage Engineering, 129 (5), pp. 360-370.
[35] Garcia, M., Raes, D., Allen, R. and Herbas, C., 2004. Dynamics of reference evapotranspiration in the Bolivian highlands (Altiplano). Agricultural and forest meteorology, 125 (1-2), pp. 67-82.

[36] Zhao, C., Nan, Z. and Cheng, G., 2005. Evaluating methods of estimating and modelling spatial distribution of evapotranspiration in the middle Heihe River basin, China. American Journal of Environmental Sciences, 1 (4), pp. 278285.

[37] Penman, H. L., 1963. Vegetation and hydrology. Soil Science, $96(5)$, p. 357.

[38] Djaman, K., Balde, A. B., Sow, A., Muller, B., Irmak, S., N'Diaye, M. K., Manneh, B., Moukoumbi, Y. D., Futakuchi, K. and Saito, K., 2015. Evaluation of sixteen reference evapotranspiration methods under sahelian conditions in the Senegal River Valley. Journal of Hydrology: regional studies, 3, pp. 139-159.

[39] Pereira, A. R. and Pruitt, W. O., 2004. Adaptation of the Thornthwaite scheme for estimating daily reference evapotranspiration. Agricultural Water Management, 66 (3), pp. 251-257.

[40] Trajkovic, S., Gocic, M., Pongracz, R., Bartholy, J. and Milanovic, M., 2020. Assessment of Reference Evapotranspiration by Regionally Calibrated TemperatureBased Equations. KSCE Journal of Civil Engineering, 24 (3), pp. 1020-1027.

[41] Hussein, A. S., 1999. Grass ET estimates using Penman-type equations in Central Sudan. Journal of irrigation and Drainage Engineering, 125 (6), pp. 324-329.

[42] Trajkovic, S., Gocic, M., Pongracz, R. and Bartholy, J., 2019. Adjustment of Thornthwaite equation for estimating evapotranspiration in Vojvodina. Theoretical and Applied Climatology, 138 (3-4), pp. 1231-1240.

[43] Lang, D., Zheng, J., Shi, J., Liao, F., Ma, X., Wang, W., Chen, X. and Zhang, M., 2017. A comparative study of potential evapotranspiration estimation by eight methods with FAO Penman-Monteith method in southwestern China. Water, 9 (10), p. 734.

[44] Afzaal, H., Farooque, A. A., Abbas, F., Acharya, B. and Esau, T., 2020. Computation of Evapotranspiration with Artificial Intelligence for Precision Water Resource Management. Applied Sciences, 10 (5), p. 1621.

[45] Gundalia, M. and Dholakia, M., 2016. Modelling Daily Reference Evapotranspiration in Middle South Saurashtra Region of India for Monsoon Season using Dominant Meteorological Variables and the FAO-56 Penman-Monteith Method. Int. J. of Sustainable Water \& Environmental Systems, 8 (2), pp. 101-108.

[46] Moeletsi, M. E., Walker, S. and Hamandawana, H., 2013. Comparison of the Hargreaves and Samani equation and the Thornthwaite equation for estimating dekadal evapotranspiration in the Free State Province, South Africa. Physics and Chemistry of the Earth, Parts A/B/C, 66, pp. 4-15. 